\title{
Phylogenetic relationships among species of the subsection Dendrophlomis Bentham
}

\author{
Ertuğrul Yüzbaşığlu* \\ Department of Biology \\ Faculty of Arts and Sciences \\ Erciyes University \\ Kayseri 38039, Turkey \\ Tel: 903524374937 Ext. 33062 \\ Fax: 903524374933 \\ E-mail: yuzbasie@erciyes.edu.tr
Mehmet Yaşar Dadandı
Department of Biology
Faculty of Arts and Sciences
Erciyes University
Kayseri 38039, Turkey
Tel: 903524374937 Ext. 33069
Fax: 903524374933
E-mail: dadandi@erciyes.edu.tr

Financial support: This study was funded by the Erciyes University Research Grant FBA-03-23 and EUBAP- 01-052-17.

Keywords: genetic diversity, genetic relationships, genetic variation, Phlomis species, RAPDs.

Abbreviations:
AMOVA: analysis of molecular variance
ITS: internal transcribed spacer
PCR: polymerase chain reaction
RAPDs: randomly amplified polymorphic DNA
UPGMA: unweighted pair-group method with arithmetic averages

This study used randomly amplified polymorphic DNA markers to determine genetic relationships among species of the subsection Dendrophlomis. Twenty accessions of the eleven Phlomis taxa were evaluated to determine genetic variability using fourteen ten mer primers selected from a 125 random oligonucleotide set. These 14 selected primers generated 85 RAPD bands that ranged in size from 200 to 1200 base pairs. Of the total bands, $88 \%$ (75) were polymorphic among the samples. Genetic distances among accessions were computed to produce a dendrogram based on UPGMA. Genetic distances ranged from 0.133 (between $P$. amanica and $P$. monocephala) to 0.494 (between $P$. chimerae and $P$. Iunariifolia). The UPGMA tree based on distances has two major groups. The first comprised 9 taxa that were clustered into two subgroups. The first subgroup consisted of $P$. viscosa, $P$. lycia, $P$. amanica and $P$. monocephala while the second comprised $P$. lunariifolia, $P$. bourgaei, $P$. longifolia var. longifolia, $P$. grandiflora var. grandiflora and $\boldsymbol{P}$. grandiflora var. fimbrilligera. The second group comprised 2 species, $P$. leucophracta and $P$. chimerae. Species-specific bands were observed for $P$. lycia, $P$. leucophracta, $P$. lunariifolia, $P$. bourgaei, $P$. chimerae and $P$. Iongifolia var longifolia.
The genus Phlomis L. comprises over 100 species including herbs, shrubs and sub-shrubs of the family Lamiaceae (Albaladejo et al. 2005). The genus is divided into two main sections, Phlomis and Phlomoides (Moench, 1794). Both sections are spread from the Mediterranean region to central Asia and China; but while species of the section Phlomoides occur mostly in central Asia and China, species of the section Phlomis appear mainly in the Mediterranean region. Turkey and Iran were indicated as the main centers of diversification in the Mediterranean region for the section Phlomis (Hedge, 1986). In particular, southern and eastern parts of the former and north-western part of the latter were proposed as centers of origin of that section. Nevertheless, Turkey has twice the number of species (34) and also nearly twice a higher endemism rate $(57 \%)$ of species belonging to section Phlomis compared to Iran, where the numbers are $18 \%$ and $33 \%$ respectively (Hedge, 1986).

Measurement of genetic variation within and between plant species is important for several reasons including delimitation of species, conservation of endangered species and construction of phylogenetic relationships among species. Several kinds of methods were used to measure levels and patterns of genetic variation, which range from

*Corresponding author 


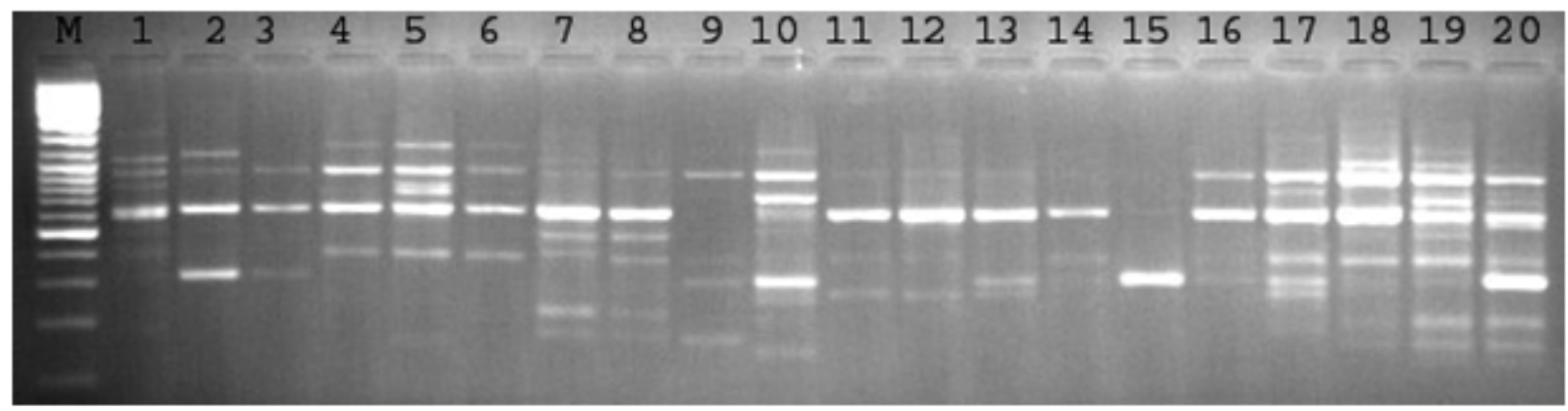

Figure 1. RAPD profile produced from the primer, OPD-12. ( $M=$ size marker, and 1-20 refer to the numbers in Table 1).

morphological characterization to various DNA-based markers such as restriction fragment length polymorphism (RFLPs), randomly amplified polymorphic DNA (RAPDs), amplified fragment length polymorphism (AFLPs) and simple sequence repeats (SSRs) (Crawford, 2000; Newton et al. 2002; Martinez et al. 2003; Fontaine et al. 2004; Murtaza, 2006; Nakazawa and Yahara, 2007). RAPD is a useful DNA-based method for assessment of genetic variation in species and genetic relationships between species due to its simplicity, speed and relatively low cost (Williams et al. 1990; Fischer et al. 2000). Due to advantages associated with RAPD, it has been widely used in plants to investigate genetic relationships among species and genetic diversity within species (Esselman et al. 2000; Rout et al. 2003; Castiglioni and De Campos, 2005; Choudhury et al. 2006; Fernandez et al. 2006; Sheng et al. 2006; Yuzbasioglu et al. 2006).

Some studies have been conducted to elucidate relationships among some Phlomis species by using morphological, anatomical, palynological and cytological traits (Huber-Morath, 1982; Hedge, 1986; Taylor, 1998). In Phlomis, based on these studies, two main sections have been recognized: Phlomis and Phlomoides, with the former section being subdivided into three subsections, Gymnophlomis, Dendrophlomis and Oxyphlomis. Species in section Phlomis have corolla with curved upper lip and trifid lower lip with large median and smaller lateral lobes whereas species in section Phlomoides have corolla with straight upper lip and trifid lower lip with sub equal lobes. Bracteoles in subsection Dendrophlomis are numerous, linear-subulate to lanceolate and ovate (Azizian and Moore, 1982). Most species in subsection Oxyphlomis have numerous rigid, linear-subulate bracteoles, which are sub equal (and sometimes longer) to the calyx. Bracteoles in subsection Gymnophlomis are weak, few to many or absent, linear-subulate, small $(2-10 \mathrm{~mm})$, free at the base and deciduous (Azizian and Moore, 1982). Natural hybrids between Phlomis species are frequently detected in local floras from several countries such as Spain, Iran and Turkey, which has lead to some confusion in differentiating species due to the mix of morphological characters observed in the hybrids and their parental species
(Albaladejo et al. 2005). Nevertheless, little is known about genetic relationship among Phlomis species at the DNA level. To our knowledge, the study of Albaladejo et al. (2005) dealing with phylogenetic relationships among Iberian Phlomis species is the only one conducted in the genus so far. In the Flora of Turkey, the genus Phlomis is represented by 34 species, six varieties and ten natural hybrids (Huber-Morath, 1982). Of the 34 species, 4, 13 and 16 were placed under the subsections Oxyphlomis, Gymnophlomis and Dendrophlomis, respectively. Among the 13 species belonging to the subsection Dendrophlomis, 9 are endemic of Turkey, including P. amanica, $P$. bourgaei, $P$. chimerae, $P$. grandiflora var. fimbrilligera, $P$. leucophracta, $P$. longifolia var. bailanica, P. lycia, $P$. monocephala and P. russeliana (Huber-Morath, 1982). P. amanica and $P$. grandiflora var. fimbrilligera were considered as endangered and vulnerable, respectively but the others were found under lower risk (Ekim et al. 2000). Moreover, $P$. chimerae and P. amanica are known as local endemics, the former only grows in around Cirali, Antalya and the latter in only around Arsuz, Hatay. In Turkey, Phlomis species have been named as ballık otu, çalba, şalba and calba in public and also been used as tonic, carminative, appetizer and stimulants in folk medicine (Baytop, 1999; Gurbuz et al. 2003). To date, no study based on DNA markers has been made to investigate phylogenetic relationships among species of the subsection Dendrophlomis native to Turkey. The objective of the present study is to determine genetic relationships among species of the subsection Dendrophlomis by using RAPD markers.

\section{MATERIALS AND METHODS}

\section{Plant material and DNA isolation}

Locations, altitudes and collection periods of the plant materials used in this study are given in Table 1. Voucher specimens of samples were kept at the Herbarium of Erciyes University, Faculty of Science and Letters, Kayseri, Turkey. For each taxon, dried leaves of single plants from the herbarium material were ground to powder in porcelain mortars with liquid nitrogen. Genomic DNA was extracted 
from $0.150 \mathrm{~g}$ powder using a modification of the method of Rogers and Bendich (1988). The powder was transferred into $0.6 \mathrm{ml}$ of CTAB extraction buffer within $1.5 \mathrm{ml}$ tubes containing $100 \mathrm{mM}$ Tris- $\mathrm{HCl}, 20 \mathrm{mM}$ EDTA, $4 \mathrm{M} \mathrm{NaCl}$, $7 \%$ CTAB (Rogers and Bendich, 1988). To this, 2\% PVP (polyvinilpyrolidone), 1\% 2-mercaptoethanol, 2\% ascorbic acid and $1 \%$ sodium bisulfate were added and incubated at $65^{\circ} \mathrm{C}$ in a water bath for $30 \mathrm{~min}$. The mixture was treated with $0.5 \mathrm{ml}$ chloroform / isoamyl alcohol (24:1) and shaked gently by inverting the tubes 50 times. The tubes were put on ice for $20 \mathrm{~min}$ to chill out polysaccharides and centrifuged at $9000 \mathrm{rpm}$ for $9 \mathrm{~min}$. Once the supernatant was transferred into new tubes, the 24 chloroform: 1 isoamyl alcohol, chilling and centrifugation steps were repeated. After centrifugation, $30 \mathrm{mg} / \mathrm{ml}$ RNAase was added and the tubes were incubated in a water bath at $37^{\circ} \mathrm{C}$ for $1 \mathrm{hr}$. Then $0.5 \mathrm{ml}$ of isopropanol was added to precipitate DNA overnight at $-20^{\circ} \mathrm{C}$. The precipitate was centrifuged to pellet DNA. The pellet was washed with $70 \%$ and $95 \%$ ethanol, air dried, redissolved in TE buffer (50 mM Tris- $\mathrm{HCl}, 10 \mathrm{mM}$ EDTA) and stored at $4^{\circ} \mathrm{C}$.

\section{RAPD procedure}

A hundred and twenty five ten mer RAPD primers were obtained from Operon Technologies, (Alameda, California, USA) and tested for amplification in a preliminary study. The primers OPA-4, OPA-10, OPA-17, OPA-18, OPA-20, OPB-17, OPB-18, OPB-20, OPD-6, OPD-8, OPD-10, OPD-12, OPD-18 and OPD-19 were then selected to analyze the genetic variability of the samples because they produced distinct and reproducible bands. DNA amplifications were carried out in $25 \mu \mathrm{l}$ of final volume containing $10 \mathrm{mM}$ Tris- $\mathrm{HCl}, 50 \mathrm{mM} \mathrm{KCl}, 0.1 \%$ Triton X$100,4 \mu \mathrm{M}$ RAPD primer, $150 \mu \mathrm{M}$ dNTPs, $2 \mathrm{mM} \mathrm{MgCl}_{2}$, $100 \mathrm{ng}$ DNA template and $2 \mathrm{U}$ Taq DNA polymerase (Fermentas). The mixture was placed in a T-Gradient (Techne) thermocycler. The PCR profile consisted of an initial step of $2 \mathrm{~min}$ at $94^{\circ} \mathrm{C}$, followed by 44 cycles of $1 \mathrm{~min}$ at $94^{\circ} \mathrm{C}, 1 \mathrm{~min}$ at $36^{\circ} \mathrm{C}$ and $2 \mathrm{~min}$ at $72^{\circ} \mathrm{C}$, with a final extension step of $5 \mathrm{~min}$ at $72^{\circ} \mathrm{C}$.

Amplification products were separated by electrophoresis on $1.6 \%$ agarose gels in a $1 \mathrm{X}$ TBE buffer. Gels were stained with ethidium bromide and photographed over UV light. Molecular weights were estimated by reference to a Gene Ruler DNA ladder (SMO331, Fermentas).

\section{Data analysis}

RAPD bands were scored in a binary manner as either present (1) or absent (0) and entered into a binary data matrix. Only RAPD bands that could be unambiguously scored were included in the analysis. A pairwise similarity matrix was constructed using the simple matching coefficient (SM) (Sokal and Michener, 1958) and NTSYSpc (Version 1.7, Rohlf, 1992). SM $=\mathrm{m} / \mathrm{n}$, where $\mathrm{m}=$ shared present fragments $(11)+$ shared absent fragments $(00)$ and $\mathrm{n}=$ the total of the obtained fragments. A pairwise genetic distance matrix was produced by subtracting the similarity coefficients from 1. A dendrogram based on the distance matrix was produced using the unweighted pair-group method with arithmetic averages (UPGMA) under the NJ subprogram in the PHYLIP software package version 3.6a3 (Felsenstein, 2002).

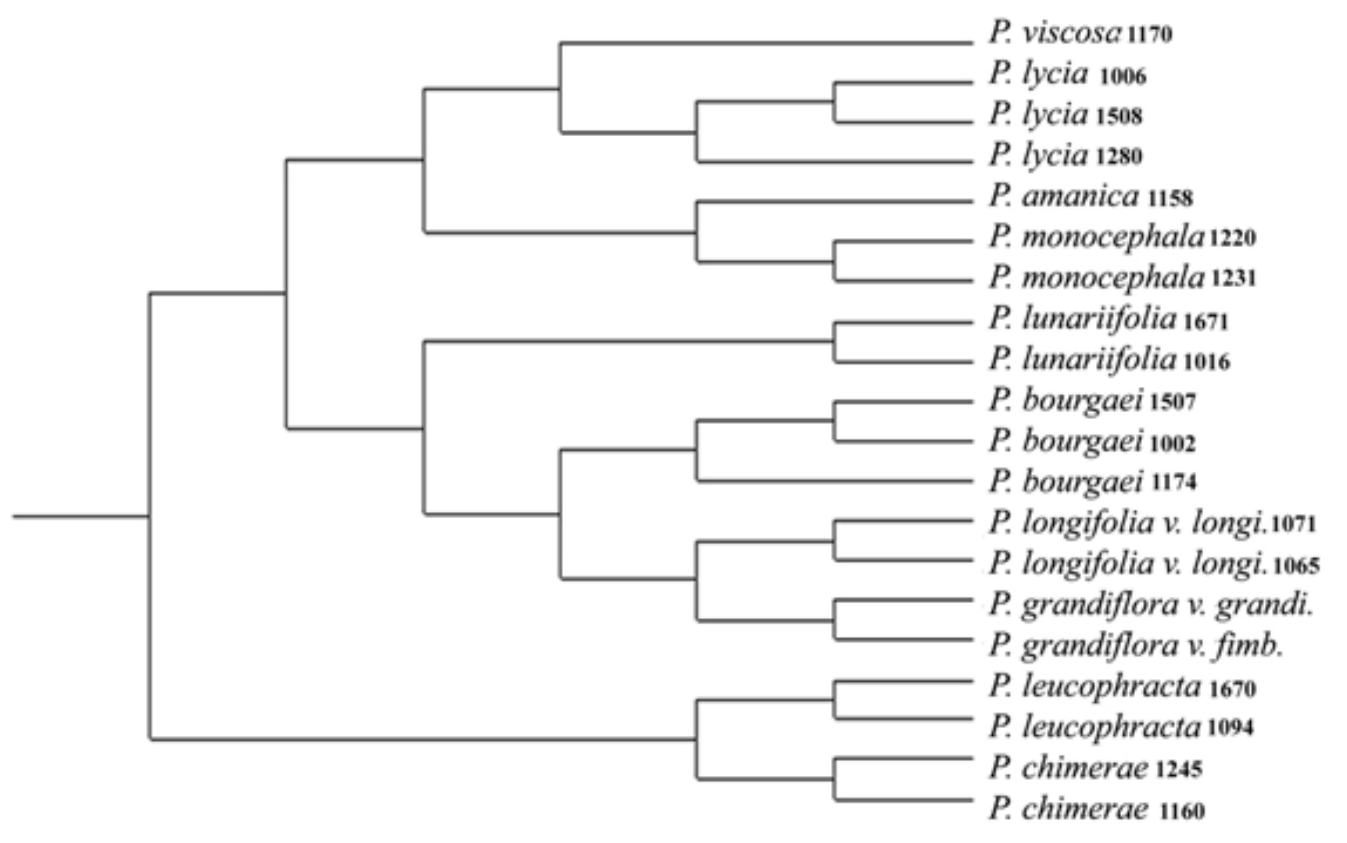

Figure 2. UPGMA phylogram of 11 Phlomis taxa in the subsection Dendrophlomis based on genetic distances. 


\section{RESULTS AND DISCUSSION}

RAPD markers have been widely used in the analysis of genetic relationships and genetic diversity in a number of plant taxa because of its simplicity, speed and relatively low cost compared to other DNA-based markers (Esselman et al. 2000; Rout et al. 2003; Sheng et al. 2006; Yuzbasioglu et al. 2006). Nevertheless, dominant inheritance and repeatability of the bands have been the two main limitations with the use of RAPD technique in the assessment of genetic diversity and genetic relationships (Fischer, 2000). However, the limitation relating to the dominant nature of RAPD bands can be compensated to some degree by examining a large number (more than 30 ) of RAPD loci (Gillies et al. 1999). Reproducibility of RAPD bands can also be improved by isolating pure DNA, selecting primers that have clear amplification patterns and maintaining consistent reaction conditions during amplification (Weising et al. 1995). DNA isolation was optimized in this study by taking these considerations into account and pure DNA was obtained by adding $2 \%$ polyvinilpyrolidone (PVP), 2\% 2-mercaptoethanol, 2\% ascorbic acid, $4 \mathrm{M} \mathrm{NaCl}$ and $7 \% \mathrm{CTAB}$ to the extraction buffer of Rogers and Bendich (1988) because Phlomis species were rich in secondary metabolites (Takeda et al. 1999; Calis et al. 2004; Calis and Kirmizibekmez, 2004; Celik et al. 2005) that caused the changes in the DNA colour (from white to yellow, red, brown and black) and weak DNA amplification in PCR (Weising et al. 1995; Yuzbasioglu et al. 2006). The concentrations of magnesium chloride, primer, template DNA, dNTPs and Taq DNA polymerase were optimized to obtain repeatable banding pattern and maintained constant during amplification. Lastly, of the 125 RAPD primers screened for their amplification capacity, fourteen primers produced clear and reproducible RAPD bands across all the species and were chosen and used for the first time to measure genetic relationships among species of the subsection Dendrophlomis. These 14 selected primers generated 85 RAPD bands that ranged in size from 200 to 1200 base pairs. Each random primer amplified between 3 and 9 RAPD bands with an average of 6 bands per primer. Of the total bands, $88 \%$ (75) were polymorphic among the 20 individuals. Figure 1 illustrates an example of a RAPD profile produced by primer OPD-12.

Genetic relationships among the eleven Phlomis taxa are indicated in the UPGMA tree (Figure 2). The topology of the UPGMA tree shows the expected groupings with relation to the taxonomic structure of the taxa used in this study. Based on the UPGMA tree, 11 taxa were divided into two major groups. The first group comprised 9 taxa that were separated into two subgroups. The first subgroup consisted of $P$. viscosa, $P$. lycia, $P$. amanica and $P$. monocephala while the second comprised $P$. lunariifolia, $P$. bourgaei, P. longifolia var. longifolia, P. grandiflora var. grandiflora and $P$. grandiflora var. fimbrilligera. Apart from $P$. viscosa within the first sub-group, calyx teeth of all are equal or shorter than $2 \mathrm{~mm}$. Within the second sub- group, $P$. lunariifolia makes a separate group with others and it differs from them having calyx with glabrose base while the others have entirely stellate-hairy calyx. Bracteols and calyx are densely long hispid-viscid in P. bourgaei but eglandular in $P$. longifolia var. longifolia. On the other hand, bracteols in $P$. grandiflora var. grandiflora and fimbrilligera are glandular-dotted but not hispid-viscid. The second group was represented by two species, i.e. P. leucophracta and $P$. chimerae. These two species are similar to each other in terms of their cauline and floral leaves shape (ovate) and calyx teeth length (between 3 and $10 \mathrm{~mm}$ ). However, $P$. leucophracta differs from $P$. chimerae and from all other species in the tree having galea with brown colour (others yellow). On the other hand, $P$. chimerae also differs from $P$. leucophracta and from all other species in the tree by having clearly branched bracteoles and basal leaves with orbicular shape. The lowest genetic distance $(0.133)$ was observed between $P$. amanica and $P$. monocephala (Table 2) and this finding is in agreement with the result of a morphological study by Taylor (1998), which indicates that $P$. amanica is similar to $P$. monocephala in terms of its habit, leaf shape and hairiness. The hairs of the calyces and bracteoles are only stellate in $P$. amanica, but in P. monocephala are long, stellate and form a very dense covering (Taylor, 1998). The highest genetic differentiation (0.494) was found between $P$. lunariifolia and $P$. chimerae in the present study (Table 2) and these two indicate differences in terms of shape, apex and margin of basal, cauline and floral leaves but similarities in terms of base of cauline and floral leaves. $P$. lunariifolia has linear-lanceolate to oblong lanceolate basal leaves which are acute to broadly acute at the apex and cuneate at the base and linear-lanceolate to oblonglanceolate floral leaves which are acute at the apex and cuneate at the base. On the other hand, P. chimerae has orbicular to broadly ovate basal leaves which are obtuse at the apex and obtuse to truncate at the base and ovate floral leaves which are obtuse at the apex and cuneate at the base. The study of Albaladejo et al. (2005) dealing with the genetic relationships among Iberian Phlomis species based on DNA markers has been the only one so far. By using three non-coding chloroplast DNA regions and nuclear ribosomal internal transcribed spacer (ITS), they investigated the genetic relationships among $P$. crinita subsp. crinita (8 accessions), P. crinita subsp. malacitana (14 accessions), $P$. crinita subsp. mauritanica (3 accessions), $P$. lychnitis (23 accessions) and $P$. purpurea as the outgroup (1 accession) and found contrasting results derived from the nuclear and plastid markers. While the dendrogram produced from the nuclear ITS data revealed two lineages (crinita and lychnitis), the grouping based on the analysis of chloroplast sequences was geographic rather than taxonomic. In the present study, the accessions grouped into their distinct species clusters and species were also clearly differentiated from each other in the dendrogram.

Classification of several Phlomis species based on morphological characters has sometimes been difficult 
because they hybridize easily in nature leading to the formation of hybrid plants with a mosaic of morphological characters between the parental phenotypes (Albaladejo et al. 2005; Yuzbasioglu et al. 2008). Hybrization between Phlomis species has been indicated by using morphological data (Albaladejo et al. 2004), isozymes (Aparicio et al. 2000) and DNA markers such as ITS (Albaladejo et al. 2005) and RAPDs (Yuzbasioglu et al. 2008). Albaladejo et al. (2004) studied natural hybridization between P. lychnitis and $P$. crinita subsp. malacitana in Andalusia (south of the Iberian Peninsula) and estimated a hybridization rate of $21.6 \%$ within the Phlomis populations by using morphometric analysis. Recently, Albaladejo and Aparicio (2007) investigated the population genetic structure and hybridization rate of this complex by using allozymes and found an average hybridization rate of $32 \%$, and concluded that the discrepancy between morphological and genetic hybridization rates could be due to the high occurrence of slightly introgressed individuals having morphology indistinguishable from that of the parental types. In parallel to the findings of Albaladejo et al. (2004) and Albaladejo and Aparicio (2007) in Spain, hybridization between Phlomis species has also been detected frequently in Turkey and 12 hybrids were registered in the flora of Turkey (Huber-Morath, 1982; Dadandi, 2003; Dadandi and Duman, 2003). In this study species-specific bands were found for $P$. lycia, $P$. leucophracta, $P$. lunariifolia, $P$. bourgaei, $P$. chimerae and $P$. longifolia var longifolia (Table 3). Primers OPD-12, OPA-109 and OPB-18 produced bands of 1030, 450 and 1030 base pairs of size, all of which were absent in P. longifolia var. longifolia, $P$. monocephala and $P$. grandiflora var. grandiflora respectively, but present in the other sampled taxa. Some bands (300 and $700 \mathrm{bp}$ from OPA-4; 600 and $700 \mathrm{bp}$ from OPB-17; $300 \mathrm{bp}$ from OPD-8 and $200 \mathrm{bp}$ from OPA-10) were observed in all of 20 samples that could be specific to the subsection Dendrophlomis. After checking more individuals within each species, species specific bands can be used for detecting instances of natural interspecific gene introgression between Phlomis species, which can provide contribution to the classification of Phlomis species made based on morphological characters. Among 13 Phlomis species placed under the subsection Dendrophlomis in the flora of Turkey, P. amanica, P. chimerae, P. bourgaei, P. leucophracta, $P$. lycia, $P$. russeliana, $P$. grandiflora, $P$. longifolia and $P$. monocephala were reported as endemic to Turkey and the species-specific bands observed in some of these endemic species including $P$. lycia, $P$. leucophracta, $P$. bourgaei and $P$. chimerae could also be used to identify Phlomis species in danger for preservation purposes. In conclusion, these results demonstrate the utility of using RAPD markers to characterize interspecific relationships and identify unique bands in Phlomis species.

\section{ACKNOWLEDGMENTS}

We would like to thank Sema Yuzbasioglu for correction of English.

\section{REFERENCES}

ALBALADEJO, R.G.; APARICIO, A. and SILVESTRE, S. Variation patterns in the Phlomis $x$ composita (Lamiaceae) hybrid complex in the Iberian Peninsula. Botanical Journal of Linnean Society, May 2004, vol. 145, p. 97-108.

ALBALADEJO, R.G.; AGUILAR, J.F.; APARICIO, A. and FELINER, G.N. Contrasting nuclear-plastidial phylogenetic patterns in the recently diverged Iberian Phlomis crinita and P. lychnitis lineages (Lamiaceae). Taxon, November 2005, vol. 54, p. 987-998.

ALBALADEJO, R.G. and APARICIO, A. Population genetic structure and hybridization patterns in the Mediterranean endemics Phlomis lychnitis and P. crinita (Lamiaceae). Annals of Botany, October 2007, vol. 100, no. 4, p. 735-746.

APARICIO, A.; ALBALADEJO, R.G.; PORRAS, M. and CEBALLOS, G. Isozyme evidence for natural hybridization in Phlomis (Lamiaceae): Hybrid origin of the rare P. x margaritae. Annals of Botany, January 2000, vol. 85 , no. 1, p. $7-12$.

AZIZIAN, D. and MOORE, D.M. Morphological and palynological studies in Phlomis L., Eromostachys Bunge and Paraphlomis Prain (Labiatae). Botanical Journal of Linnean Society, 1982, vol. 85, p. 225-248.

BAYTOP, T. Therapy with medicinal plants in Turkey, past and present. $2^{\text {nd }}$ ed. Nobel Tip Basımevi, İstanbul, Turkey, 1999, 193 p. ISBN 9754200211.

CALIS, I.; KIRMIZIBEKMEZ, H.; TASDEMIR, D. and RUEDI, P. Two new triterpene and a new nortriterpene glycosides from Phlomis viscosa. Helvetica Chimica Acta, March 2004, vol. 87, no. 3, p. 611-619.

CALIS, I. and KIRMIZIBEKMEZ, H. Glycosides from Phlomis lunariifolia. Phytochemistry, September 2004, vol. 65 , no. 18 , p. $2619-2625$.

CASTIGLIONI, L. and DE CAMPOS, H.E.M. Molecular characterization and relatedness of Haematobia irritans (horn fly) populations, by RAPD-PCR. Genetica, May 2005, vol. 124, no. 1, p. 11-21.

CELIK, S.; GOKTURK, R.S.; FLAMINI, G.; CIONI, P.L. and MORELLI, I. Essential oils of Phlomis leucophracta, Phlomis chimerae and Phlomis grandiflora var. grandiflora from Turkey. Biochemical Systematics and Ecology, June 2005, vol. 33, no. 6, p. 617-623.

CHOUDHURY, P.R.; TANVEER, H. and DIXIT, G.P. Identification and detection of genetic relatedness among important varieties of pea (Pisum sativum L.) grown in India. Genetica, October 2006, vol. 130, no. 2, p. 183-191. 
CRAWFORD, D.J. Plant macromolecular systematics in the past 50 years: one view. Taxon, 2000, vol. 49, no. 3, p. 479-490.

DADANDI, M.Y. and DUMAN, H. A new natural hybrid of Phlomis (Lamiaceae) from Turkey. Annales Botanici Fennici, August 2003, vol. 40, no. 4, p. 287-290.

DADANDI, M.Y. A new natural hybrid of Phlomis L. (Lamiaceae) from South Anatolia. The Karaca Arboretum Magazine, December 2003, vol. 7, no. 2, p. 59-66.

EKIM, T.; KOYUNCU, M.; VURAL, M.; DUMAN, H.; AYTAC, Z. and ADIGUZEL, N. Red data book of Turkish plants (Pteridophyta and Spermatophyte). TTKD and Van Centennial University Press, Ankara, Turkey, 2000, p. 100, 171. ISBN 975-93611-0-8.

ESSELMAN, E.J.; CRAWFORD, D.J.; BRAUNER, S.; STUESSY, T.F.; ANDERSON, G.J. and SILVA, O.M. RAPD marker diversity within and divergence among species of Dendroseris (Asteraceae: Lactuceae). American Journal of Botany, April 2000, vol. 87, no. 4, p. 591-596.

FELSENSTEIN, J.P. (Phylogeny Inference Package) version 3.6a3. Distributed by the author. Department of Genome Sciences, University of Washington, Seattle. 2002.

FERNANDEZ, R.M.; VALENZUELA, A.S. and BALOCCHI, L.C. RAPD and freezing resistance in Eucalyptus globus. Electronic Journal of Biotechnology, June 2006, vol. 9, no. 3, p. 303-309.

FISCHER, M.; HUSI, R.; PRATI, D.; PEINTINGER, M.; VAN KLEUNEN, M. and SCHMID, B. RAPD variation among and within small and large populations of the rare clonal plant Ranunculus reptans (Ranunculaceae). American Journal of Botany, August 2000, vol. 87, no. 8, p. 1128-1137.

FONTAINE, C.; LOVETT, P.N.; SANOU, H.; MALEY, J. and BOUVET, J.M. Genetic diversity of the shea tree (Vitellaria paradoxa C.F. Gaertn), detected by RAPD and chloroplast microsatellite markers. Heredity, December 2004, vol. 93, no. 6, p. 639-648.

GILlIES, A.C.M.; NAVARRO, C.; LOWE, A.J.; NEWTONS, A.C.; HERNANDEZ, M.; WILSON, J. and CORNELIUS, J.P. Genetic diversity in Mesoamerican populations of mahogany (Swietenia macrophylla), assessed using RAPDs. Heredity, December 1999, vol. 83, no. 6 , p. $722-732$.

GURBUZ, I.; USTUN, O.; YESILADA, E.; SEZIK, E. and KUTSAL, O. Anti-ulcerogenic activity of some plants used as folk remedy in Turkey. Journal of Ethnopharmacology, 2003, vol. 88, no. 1, p. 93-97.
HEDGE, I.C. Labiatae of South-West Asia: diversity, distribution and endemism. Proceedings of the Royal Society of Edinburgh, 1986, vol. 89B, p. 23-35.

HUBER-MORATH, A. Phlomis L. In: DAVIS, P.H. ed. Flora of Turkey and East Aegean Island. Edinburgh; Edinburgh University Press, 1982, vol. 7, p. 102-126.

MARTINEZ, L.; CAVAGNARO, P.; MASUELLI, R. and RODRIGUEZ, J. Evaluation of diversity among Argentina grapevine (Vitis vinifera L.) varieties using morphological data and AFLP markers. Electronic Journal of Biotechnology, December 2003, vol. 6, no. 3, p. 241-250.

MOENCH, C. Methodus plantas Horti botanici et agri Margurgensis a straminium situ describendi, 1794.

MURTAZA, N. Cotton genetic diversity study by AFLP markers. Electronic Journal of Biotechnology, July 2006, vol. 9 , no. 4 , p. $456-460$.

NAKAZAWA, M. and YAHARA, T. Amplified fragment length polymorphism analysis of the genetic variation of an endangered plant Lysimachia tashiroi (Myrsinaceae). Plant Species Biology, April 2007, vol. 22, no. 1, p. 33-39.

NEWTON, A.C.; ALLNUT, T.R.; DWORAK, W.S.; DEL CASTILLO, R.F. and ENNOS, R.A. Patterns of genetic variation in Pinus chiapensis, a threatened Mexican pine, detected by RAPD and mitochondrial DNA RFLP markers. Heredity, September 2002, vol. 89, no. 3, p. 191-198.

ROGERS, S.O. and BENDICH, A.J. Extraction of DNA from milligram amounts of fresh, herbarium and mummified plant tissues. Plant Molecular Biology, 1988, vol. 5, no. 2, p. 69-76.

ROHLF, F.J. NTSYS-pc numerical taxonomy and multivariate analysis system version 1.7. Exeter Publications, New York, 1992.

ROUT, G.R.; BHATACHARYA, D.; MANDA, R.M.; NAYAK, S. and DAS, P. Evaluation of genetic relationships in Dalbergia species using RAPD markers. Biodiversity and Conservation, February 2003, vol. 12, no. 2, p. 197-206.

SHENG, H.M.; AN, L.Z.; CHEN, T.; XU, S.J.; LIU, G.X.; ZHENG, X.L.; PU, L.L.; LIU, Y.J. and LIAN, Y.S. Analysis of the genetic diversity and relationships among and within species of Hippophae (Elaeagnaceae) based on RAPD. Plant Systematics and Evolution, August 2006, vol. 260, no. 1, p. 25-37.

SOKAL, R.R. and MICHENER, C.D. A statistical method for evaluating systematic relationships. University of Kansas Science Bulletin, 1958, vol. 38, p. 1409-1438.

TAKEDA, Y.; KINUGAWA, M.; MASUDA, T.; HONDA, G.; OTSUKA, H.; SEZIK, E. and YESILADA, E. 
Phlomisethanoside, a phenylethanoid glycoside from Phlomis grandiflora var. grandiflora. Phytochemistry, May 1999, vol. 51, no. 2, p. 323-325.

TAYLOR, J.M. Phlomis, the neglected genus, a guide for gardeners and horticulturists. National Council for the Conservation of Plants and Gardens, Westbury-on-severn, Gloucester, England; 1998, p. 3-87. ISBN 0953241300.

WEISING, K.H.; NYBOM, W.K. and MEYER, W. DNA finger printings in plants and fungi. Boca Raton - Florida, USA; CRC Press Inc., 1995, p. 1-200. ISBN 0-8493-89208.

WILLIAMS， J.G.K.; KUBELIK， A.R.; LIVAK， K.J.; RAFALSKI, J.A. and TINGEY, S.V. DNA polimorphisms amplified by arbitrary primers are useful as genetic markers. Nucleic Acids Research, November 1990, vol. 18, no. 22, p. 6531-6535.

YUZBASIOGLU, E.; OZCAN, S. and ACIK, L. Analysis of genetic relationships among Turkish cultivars and breeding lines of Lens culinatis Mestile using RAPD markers. Genetic Resources and Crop Evolution, May 2006, vol. 53, no. 3 , p. 507-514.

YUZBASIOGLU, E.; DADANDI, M.Y. and OZCAN S. Natural hybridization between Phlomis lycia D. Don x $P$. bourgaei Boiss. (Lamiaceae) revealed by RAPD markers. Genetica, May 2008, vol. 133, no. 1, p. 13-20. 


\section{APPENDIX \\ TABLES}

Table 1. Locations, altitudes and collection periods of the plant materials used in RAPD analysis.

\begin{tabular}{|c|c|c|c|c|c|}
\hline Numbers & Code & Species & Location & Altitude (m) & Date \\
\hline 1 & 1170 & P. viscosa & B6 Adana; Feke-Adana road $2 \mathrm{~km}$ & 930 & 4.vii.1998 \\
\hline 2 & 1671 & P. Iunariifolia & 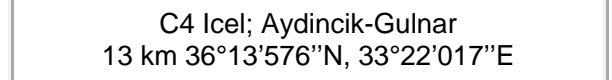 & 520 & 3.vii.2003 \\
\hline 3 & 1016 & P. lunariifolia & $\begin{array}{l}\text { C3 Antalya; Between Manavgat-Alanya, } \\
10 \mathrm{Km} \text { North of Kastel. }\end{array}$ & 700 & 31.v.1997 \\
\hline 4 & 1508 & P. lycia & $\begin{array}{l}\text { C2 Mugla; Marmaris, Bozburun, around } \\
\text { Serce limanı } 36^{\circ} 34^{\prime} 903^{\prime \prime} N, 28^{\circ} 03^{\prime} 052^{\prime \prime} E\end{array}$ & 71 & 6.v.2001 \\
\hline 5 & 1280 & P. lycia & C2 Mugla; Kale-Mugla road 52 km & $950-1000$ & 10.vi.1999 \\
\hline 6 & 1006 & P. lycia & C3 Antalya; Termessos National Park & $700-750$ & 2.vi.1997 \\
\hline 7 & 1670 & P. leucophracta & 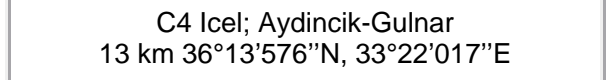 & 520 & 3.vii.2003 \\
\hline 8 & 1094 & P. leucophracta & C4 Icel; Ermenek-Mut road 50 km & $850-900$ & 24.vi.1998 \\
\hline 9 & 1245 & P. chimerae & C3 Antalya; Antalya-Kemer road 12 km & 50 & 8.vi.1999 \\
\hline 10 & 1160 & P. chimerae & C3 Antalya; Kemer, Kesme Bogazi & 150 & 27.vi.1998 \\
\hline 11 & 1002 & P. bourgaei & C3 Antalya; Termessos National Park & $700-750$ & 2.vi.1997 \\
\hline 12 & 1174 & P. bourgaei & C2 Antalya; Gursu village to Elmalı $6 \mathrm{~km}$ & 1100 & 27.vi.1998 \\
\hline 13 & 1507 & P. bourgaei & $\begin{array}{l}\text { C2 Mugla; Bozburun-Marmaris road } \\
10 \mathrm{~km}, 36^{\circ} 41^{\prime} 773^{\prime \prime} \mathrm{N}, 28^{\circ} 05^{\prime} 323^{\prime \prime} \mathrm{E}\end{array}$ & 221 & 5.v.2001 \\
\hline 14 & 1071 & P.longifolia var. longifolia & $\begin{array}{l}\text { C6 Hatay; Samandag-Yayladag seaside road, } \\
\text { between Coguntu-Gozene villages }\end{array}$ & 380 & 14.vi.1998 \\
\hline 15 & 1065 & P.longifolia var. longifolia & C6 Hatay; between Gedik and Atik & 800 & 13.vi.1998 \\
\hline 16 & 1225 & P. grandiflora var. fimbrilligera & $\begin{array}{c}\text { C4 Antalya; between Anamur-Gazipasa, } \\
\text { around Kargıdran stream }\end{array}$ & 20 & 7.vi.1999 \\
\hline 17 & 1166 & P. grandiflora var. grandiflora & $\begin{array}{l}\text { C2 Antalya; Oluk Yaylasi, between } \\
\text { Gomuce and Kuruova villages. Kas-Elmali road. }\end{array}$ & 1700 & 28.vi.1998 \\
\hline 18 & 1158 & P. amanica & $\begin{array}{l}\text { C6 Hatay; Arsuz (Ulucinar), } \\
\text { Haymaseki village, around Aktepe }\end{array}$ & $250-300$ & 9.viii.1998 \\
\hline 19 & 1220 & P. monocephala & C4 Icel; Gulnar-Silifke road 47 km & 680 & 7.vi.1999 \\
\hline 20 & 1231 & P. monocephala & C4 Icel; Gulnar-Silifke road 47 km & 680 & 7.vi.1999 \\
\hline
\end{tabular}


Table 2. Genetic distances among 11 Phlomis taxa in the subsection Dendrophlomis. Codes refer to Table 1.

\begin{tabular}{|c|c|c|c|c|c|c|c|c|c|c|c|c|c|c|c|c|c|c|c|c|}
\hline Codes & 1170 & 1671 & 1016 & 1508 & 1280 & 1006 & 1670 & 1094 & 1245 & 1160 & 1002 & 1174 & 1507 & 1071 & 1065 & 1225 & 1166 & 1158 & 1220 & 1231 \\
\hline 1170 & - & & & & & & & & & & & & & & & & & & & \\
\hline 1671 & 0.253 & - & & & & & & & & & & & & & & & & & & \\
\hline 1016 & 0.337 & 0.133 & - & & & & & & & & & & & & & & & & & \\
\hline 1508 & 0.205 & 0.362 & 0.398 & - & & & & & & & & & & & & & & & & \\
\hline 1280 & 0.193 & 0.398 & 0.434 & 0.036 & - & & & & & & & & & & & & & & & \\
\hline 1006 & 0.193 & 0.374 & 0.386 & 0.060 & 0.048 & - & & & & & & & & & & & & & & \\
\hline 1670 & 0.362 & 0.301 & 0.386 & 0.325 & 0.313 & 0.313 & - & & & & & & & & & & & & & \\
\hline 1094 & 0.349 & 0.289 & 0.398 & 0.337 & 0.325 & 0.325 & 0.012 & - & & & & & & & & & & & & \\
\hline 1245 & 0.422 & 0.386 & 0.446 & 0.362 & 0.398 & 0.398 & 0.325 & 0.313 & - & & & & & & & & & & & \\
\hline 1160 & 0.374 & 0.362 & 0.494 & 0.362 & 0.325 & 0.349 & 0.301 & 0.289 & 0.145 & - & & & & & & & & & & \\
\hline 1002 & 0.482 & 0.374 & 0.362 & 0.398 & 0.410 & 0.410 & 0.386 & 0.398 & 0.398 & 0.374 & - & & & & & & & & & \\
\hline 1174 & 0.482 & 0.374 & 0.386 & 0.398 & 0.434 & 0.434 & 0.362 & 0.374 & 0.398 & 0.422 & 0.121 & - & & & & & & & & \\
\hline 1507 & 0.362 & 0.229 & 0.289 & 0.301 & 0.337 & 0.313 & 0.337 & 0.349 & 0.349 & 0.325 & 0.169 & 0.169 & - & & & & & & & \\
\hline 1071 & 0.422 & 0.337 & 0.398 & 0.434 & 0.470 & 0.446 & 0.446 & 0.458 & 0.410 & 0.458 & 0.277 & 0.301 & 0.277 & - & & & & & & \\
\hline 1065 & 0.349 & 0.313 & 0.398 & 0.386 & 0.398 & 0.374 & 0.422 & 0.434 & 0.458 & 0.434 & 0.349 & 0.374 & 0.301 & 0.121 & - & & & & & \\
\hline 1225 & 0.349 & 0.289 & 0.374 & 0.386 & 0.398 & 0.374 & 0.422 & 0.434 & 0.434 & 0.434 & 0.325 & 0.398 & 0.277 & 0.289 & 0.241 & - & & & & \\
\hline 1166 & 0.337 & 0.374 & 0.434 & 0.325 & 0.313 & 0.313 & 0.386 & 0.398 & 0.398 & 0.374 & 0.289 & 0.386 & 0.313 & 0.349 & 0.277 & 0.157 & - & & & \\
\hline 1158 & 0.193 & 0.301 & 0.386 & 0.277 & 0.265 & 0.265 & 0.337 & 0.325 & 0.446 & 0.398 & 0.386 & 0.434 & 0.313 & 0.349 & 0.277 & 0.301 & 0.241 & - & & \\
\hline 1220 & 0.277 & 0.313 & 0.374 & 0.362 & 0.325 & 0.349 & 0.349 & 0.362 & 0.482 & 0.386 & 0.398 & 0.422 & 0.325 & 0.386 & 0.289 & 0.362 & 0.301 & 0.133 & - & \\
\hline 1231 & 0.289 & 0.301 & 0.362 & 0.374 & 0.337 & 0.362 & 0.337 & 0.349 & 0.470 & 0.374 & 0.386 & 0.410 & 0.313 & 0.374 & 0.277 & 0.349 & 0.289 & 0.145 & 0.012 & - \\
\hline
\end{tabular}

Table 3. Specific bands observed in Phlomis species.

\begin{tabular}{|l|c|c|}
\hline \multicolumn{1}{|c|}{ Phlomis species } & Primer & Band Size (base pairs) \\
\hline P. lycia & OPD-10 & 250 \\
\hline \multirow{2}{*}{ P. leucophracta } & OPD-12 & 450 \\
\cline { 2 - 3 } & OPD-6 & 600 \\
\hline P. lunariifolia & OPD-12 & 300 \\
\hline P. bougaei & OPD-12 & 300 \\
\hline & OPA-17 & 600 \\
\hline \multirow{2}{*}{ P. chimerae } & OPB-18 & 250 \\
\hline & OPB-20 & 700 \\
\hline P. longifolia var. longifolia & OPB-20 & 800 \\
\hline
\end{tabular}

